\title{
International Political Science
}

\section{Why Is There a European Political Science?*}

\author{
David McKay \\ European Consortium for \\ Political Research
}

There is much to be said for the claim that an academic discipline achieves the status of science when its theories and findings easily transcend national barriers and boundaries. A scientific breakthrough in physics or genetics established almost anywhere in the world will rapidly find its way into the leading American journals and into the everyday research agendas of scientists. It follows that in such disciplines, one professional standard really does exist, and in the non-Communist world, at least, something resembling an international marketplace has developed, not only in ideas but also in personnel.

While social science has never reached this level of professionalization (and probably never will), the increasingly mathematical nature of economics has helped create a common currency in that subject, and therefore something approaching a single standard. Western European and Asian economists, in particular, have been recruited by top American departments in some numbers, and for economists in many countries, publication in the leading American journals represents a true imprimatur of success.

Within political science, even this degree of professionalization has failed to develop. Theories and findings do cross national boundaries, of course, and there is a small international job market. For the most part, however, careers and reputations are made in one country. Often, research findings are strictly for local con- sumption. As Hans Dieter Klingemann's fascinating piece on the ranking of graduate departments suggests, not even the Canadians are integrated into a North American political science community. As he puts it: "Though [Canadians] read and cite publications in American journals, they tend to publish in Canadian jour. nals-which the vast majority of their American colleagues do not read or cite" (Klingemann 1986, 660). If this is so, what hope is there for a global political science?

The Canadian case is less interesting than the European, however. Political science in Canada is quite small (APSA's Guide to Graduate Political Science lists 477 faculty working in 25 institutions), ${ }^{\prime}$ and the Canadians are understandably defensive about their giant neighbor to the South (for a review of the development of Canadian political science, see Trent 1987). European political science is much larger. There is a minimum of 2,500 academic faculty working in over 150 institutions (Directory of European Political Scientists. 1986). ${ }^{2}$ Moreover, the Europeans have developed their own cross-national professional association, the European Consortium for Political Research (ECPR), which in terms of the services provided for members (conferences, research sponsorship, English and French speaking summer schools in quantitative methods, publications) rivals those provided by APSA. After 17 years of ECPR activity, however. there is little evidence of the two worlds of APSA and the ECPR melding together to form some sort of transatlantic political science community.

Instead, American political science seems to have developed in one direction and European political science in another. As with the Canadians, Europeans generally do not publish in American journals and with the exception of one or two English language journals, few Americans would choose to publish in a European over an 
American journal. Rarely do American scholars read, and therefore rarely do they cite, European journals.

Some of the reasons for these divergent developmental paths are obvious, and some not. Clearly, language can constitute a barrier. Most academics prefer to write in their own language, and most European journals are not published in English. Note, however, that many are (all the British and Irish journals plus Scandinavian Political Studies and the European Journal of Political Research). And language problems can be overcome if they have to be. Not so many years ago, all the world's leading chemists were required to read German because of Germany's pre-eminence in that subject. I do not see American political scientists rushing to read Politische Vierteljahresschrift, however.

Language relates to another obvious reason for the failure for one market to develop: distinctive national training requirements for higher degrees. NonFrench-language qualifications are simply not as valued in France as are French degrees. In Germany, the best jobs are available only to those who survive the long and grueling post-doctoral period culminating in the habilitation. This is a sort of super Ph.D. dissertation which candidates often do not receive until they are 40 or older. American schools, too, often look with suspicion on foreign qualifications which, no matter how demanding, do not carry with them the particular professional socialization process favored by most recruiting departments. Perhaps most important is the simple fact that patronage networks rarely transcend national borders.

But this and the other points do, to some extent, beg the question. With easy and cheap communications, a growing number of national and international conferences, and simply more political scientists doing more research, some noticeable advance towards a single market, at least in approaches and ideas, should by now have occurred. To get to the heart of this question, it is necessary to look not just at the organization of the discipline but also at intellectual developments. Very broadly, two different sorts of explanations could be invoked to account for the way in which the discipline has grown. It could be, first of all, that European political science simply has lower standards than the American variety. It may be, in a word, inferior, and unable to produce scholars who can compete in the highly discriminating American marketplace. And second, it may be that European and American political science have taken on distinctive characteristics relating to contrasting intellectual traditions. Let us look at each of these in turn.

\section{Is European Political Science Inferior?}

This is a complex, controversial, and in many ways essentially subjective question which cannot be answered definitively either here or probably anywhere else. It has to be raised, however, because some of our colleagues on both sides of the Atlantic would answer resolutely in the affirmative. The argument goes something like this. Over a long period, American political science has built up a body of knowledge in its various sub-areas as a result of a substantial investment in the best human capital available. Entry requirements are high, training rigorous, and peer group performance pressures considerable. The resulting high standards are reflected in the elevated status of a select group of graduate departments and journals. For a number of reasons, no other country or geographic region has been able to replicate this pattern. Size clearly may be relevant here. A small national community cannot expect to emulate the very best of American political science. This may help explain the allegedly minor contribution made by Canadian-based scholars to the discipline. But size should only reduce the number and quality of the contributions made by a particular national grouping. It cannot in itself account for distinctive theoretical and empirical approaches. The Europeans are, in any case, organized on a cross-national basis. The resulting community is large and varied. The crucial question is, therefore: do the Europeans generally not compete in the American market and publish in American journals because their standards 
are lower, or because their standards are different? Unfortunately quality and distinctiveness are linked in complex ways. The technical standards demanded by the American Political Science Review and other leading journals reflect the particular way in which many U.S. scholars view the political and social world. Europeans often do not have these skills because they believe that this world can be studied and understood without relying only or mainly on sophisticated methodology (a view admittedly shared by many Americans). Conceptually, European scholarship may be just as sophisticated as American. Of course it may be that Europeans prefer publication in home-grown publications for purely instrumental reasons. Put simply, their careers can progress quite satisfactorily without going through the difficult business, including learning new skills, of publishing in what are regarded as the best U.S. journals. But this brings us back to the organization rather than the intellectual thrust of the discipline.

At the level of the practical utility of research findings in respective countries or regions, there is simply no validity to the claim that American political science is superior. On the contrary, in most Continental European countries political scientists and public administrators are much more integrated into decision-making processes than they are in the United States. In such areas as budgeting, electoral and constitutional reform, and a host of discrete policy arenas, Scandinavian, German, and French political scientists are widely consulted by governments and political parties. Their status and influence is almost certainly higher than that enjoyed by their American colleagues. Admittedly this relates as much to the general status of the professorial class (or possibly of intellectuals) in these countries, as it does to the quality of their work. But if scientific findings are exposed to the rigors of real world application, some independent test of quality is likely to exist.

In Britain, the situation is different again. Few British academics find themselves walking the corridors of power. Indeed the national and local political world is more closed to academics than is the American. This accepted, British political scientists have close links with the national media. The "TV don" is commonplace in Britain. As a result, a small group of British social scientists achieve a level of national exposure-and fame-which has no equivalent in the United States.

Finally, in two major sub-fields of the discipline a general consensus exists that European political science is far from inferior. In political and social theory the European contribution has been and continues to be undisputed. This applies both to liberal and nonliberal theory, with the British continuing to be the standard bearers for the former and the French and Germans for the latter. While it could be argued that neither school has elaborated a perspective powerful enough to become something approaching paradigmatic, neither have American political theorists. or at least those theorists working within political science. ${ }^{3}$

In the general field of area or comparative politics, the European contribution is substantial. This holds at three levels. First, Europe continues to produce an impressive array of indigenous national experts. If an American specialist on Swedish, German, or British politics wants to say something new, he or she has to become familiar with the "native" political science literature which usually sets the terms of debate and controversy. Only rarely does American scholarship do so for work conducted within these countries -although it often does for debate on comparative politics within the United States. Admittedly, this also applies tout force to European students of American politics, few of whom have made any impact on American debate. But here numbers truly are of the essence. More than 10,000 U.S. political scientists are exclusively engaged in the study of their own country. Probably no more than 100 Europeans are similarly engaged with American politics. ${ }^{4}$

Second, Europe has produced among the world's finest area specialists - experts on the Soviet Union, Africa, China, and so on. This no doubt relates in part to historically established colonial and imperial ties, but the quality of this work has in no way declined since the demise of empire. Third, Europeans have pioneered 
research in what might be called structural comparative politics, or the systematic study of political institutions and processes across several and sometimes many countries. This constitutes a unique development in the discipline which Americans have contributed to rather than pioneered. I will return to this point later.

In sum, the case is not proven. American political science is undoubtedly more professionalized and in this sense maintains more consistent standards. The American profession has certainly produced a greater volume of high-quality researchers, but this is primarily a function of numbers. It is doubtful whether the average American scholar is much different from the average European. Neither in conceptual nor in methodological terms have American standards become the only benchmark for quality political science research conducted outside of the United States. As indicated, the reasons for this are complex and varied. European political science is different from, not inferior to, the American variety.

\section{Contrasting Intellectual Traditions}

In epistemological terms, it is much easier to characterize American political science than European. Broadly speaking American scholarship has been dominated by the liberal intellectual tradition. In the original legal and constitutional approach, during the behavioral revolution, and now with rational choice analysis, the individual has been and remains the basic unit of analysis. This is hardly unique to political science, of course. Indeed, the American discipline has been constructed on foundations laid by a liberal jurisprudence, economics, philosophy, and psychology. Such remains the case today with many of the higher status research breakthroughs informed by a paradigm borrowed from liberal economics.

Historically, no single tradition has dominated European political science, and even today a complex mix of liberal, structural, and collectivist approaches coexist-sometimes even in one department. This is not the place to review these approaches, but it is clear that the variety of European scholarship reflects not only contrasting intellectual traditions, but also contrasting political systems. For, while Samuel Huntington is right to claim that: "Where democracy is strong, political science is strong; where democracy is weak, political science is weak" (Huntington 1987, p. 7), it is also the case that there are different types of democracy and therefore different types of political science. Put another way, the growth of European political science in the post-war period relates directly to the emergence of democracy in a number of European countries, now including Greece, Spain, and Portugal. But in no European country is the business of politics so infused with the liberal individualism so intimately associated with the United States. Instead, European democracies are a complex melange of liberalism, corporatism, consociationalism, elitism, populism, statism, and socialism. European political science reflects this in just the same way as American political science-which is primarily concerned with the study of the United States-reflects the individualism of American politics.

The sheer complexity and variety of the European democracies may help to explain the particular organization and intellectual orientation of the ECPR. Membership (by institution, not individual) is restricted to democracies. So the founding fathers of the ECPR - Jean Blondel, Stein Rokkan, Rudolph Wildenmann, and Hans Daalder-were at one with Huntington in believing that political science scholarship can only truly exist in open societies. At the same time, the ECPR has strived hard to establish a specifically European approach to comparative politics, while remaining intellectually agnostic. Hence, the organization is closely associated with structural comparative politics, or the search for patterns of behavior across several or many political systems and subsystems. The method is inductive, highly empirical, and usually involves quantification. While this approach has met with some success as the work of Blondel, Daalder, Lijphart, Bokkan, von Beyme, and others testifies, it has not had the impact on the European discipline that behavioralism had, and rational choice is 


\section{European Political Science}

having, on American political science.

This may have something to do with the catholicism of the ECPR-as an examination of any program of the annual ECPR Joint Sessions would show-but it also reflects the complexity and variety of the European intellectual tradition and of European politics. In one sense, then, structural comparative politics represents an attempt to overcome this complexity by searching for meaningul patterns of political and social behavior among diverse states. This school of thought assumes, a priori, that democracies have important features in common, and that the study of democratic processes can help strengthen democratic institutions and values. In the context of post-war Europe, such assumptions and objectives are unsurprising. It is also unsurprising to learn that the students of structural comparative politics always accepted that their approach could never be more than complementary to, as opposed to dominant over, other approaches in the European discipline. What can be said is that because most European democracies are becoming more individualistic, so the American method and American conceptual frameworks will become more relevant. It would, for example, have been unthinkable just a few years ago to have even considered writing a book comparing the personal vote in the British House of Commons and the U.S. House of Representatives. Yet such a book has been written, and the comparison is far from inappropriate (Cain, Ferejohn, and Fiorina 1987).

\section{Conclusions}

Clearly the particular nature of European political science relates to a number of factors, organizational, linguistic, and intellectual. But as indicated, the separate developmental paths taken by the Americans and Europeans is as much a function of the distinctiveness of political systems as of these more obvious influences. Common approaches do, of course, exist. But these are insufficientiy pervasive to have produced anything approaching a single market in ideas or people. With ever improving communications and some degree of convergence between the American and European political systems, progress towards such a market is probably being made. We have a long way to go, however.

\section{About the Author}

David McKay is Reader in Government and Executive Director of the European Consortium for Political Research at the University of Essex. During 1987-88 he was Visiting Professor in Political Science at the University of California, San Diego.

\section{Notes}

*I am grateful to Arend Lijphart for comments on an earlier draft of this paper.

1. Excluding four universities, including Toronto and Montreal who failed to report faculty members.

2. The Directory of European Political Scientists is not comprehensive, but does include the majority of those who are active in the discipline.

3. The most influential work in American political and social theory has been generated by philosophers rather than by political scientists as the work of Rawls, Nozick, Walzer, and others testifies.

4. The Directory of European Political Scientists actually lists academics whose interests include the United States, but only a handful of these list the United States as their exclusive interest.

\section{References}

American Political Science Association. 1986. Guide to Groduate Study in Political Science. Washington, DC: American Political Science Association.

Cain, Bruce, John Ferejohn, and Morris Fiorina. 1987. The Personal Vote. Cambridge, Mass.: Harvard University Press.

European Consortium for Political Research. 1986. Directory of European Political Scientists. London: Hans Zell.

Huntington, Samuel P. 1988. "One Soul at a Time: Political Science and the Politics of Reform." American Political Science Review, 82(March): 3-10. 


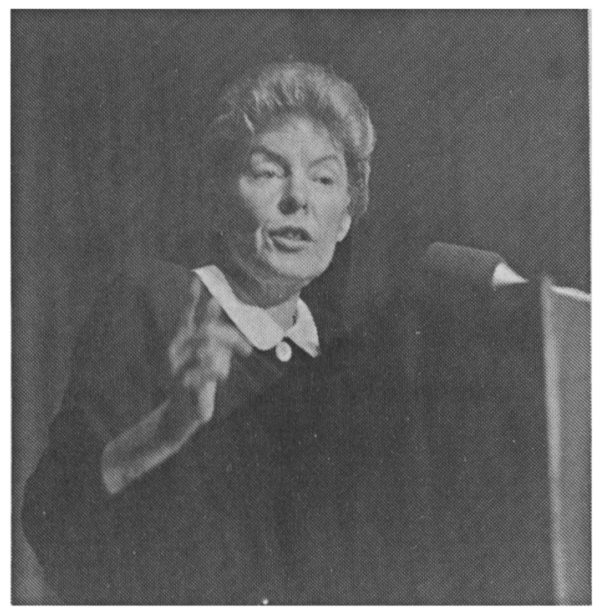

Ambassador jeane J. Kirkpatrick addresses the opening session of the IPSA 14th World Congress.

Klingeman, Hans Dieter. 1986. "Ranking the Graduate Departments in the 1980s: Toward Objective Qualitative Indicators." PS, 19(Summer): 651-661.

Trent, John E. 1987. "'Factors Influencing the Development of Political Science in Canada: A Case and a Model." Internotional Political Science Review, 8(January): 9-24.

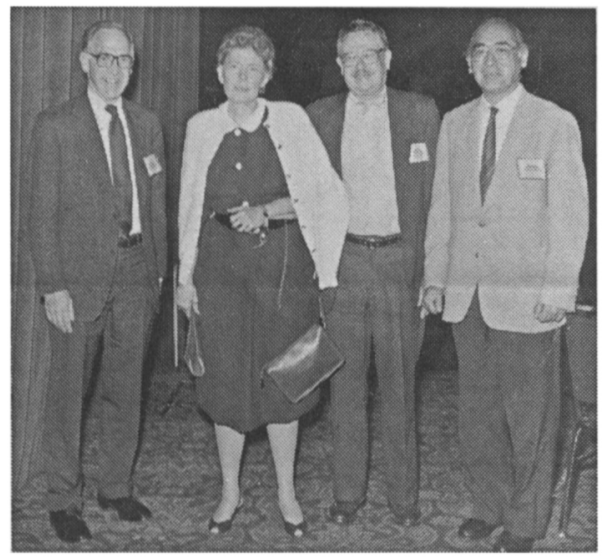

World Congress program chair, Harold Jacobson; Ambassador Jeane J. Kirkpatrick; APSA president Kenneth Waltz; and IPSA president Kinhide Mushakoji.

\section{APSA Hosted 14th World Congress of International Political Science Association}

The success of the International Political Science Association's 14th World Congress prefigured the APSA's Annual Meeting. The Washington World Congress, hosted by APSA from August 28 to September I, was the largest, most diversified, and best endowed of IPSA World Congresses.

The World Congress held at the Sheraton Washington Hotel was a homecoming for the APSA hosts. The APSA had held its $6 /$ st Annual Meeting in 1965 at the then Sheraton Park Hotel. At the time Evron Kirkpatrick was APSA Executive Director; David Truman, APSA President; and Gabriel Almond, President-Elect. The IPSA World Congress began on Sunday, August 28 with a presentation by Almond on the State of the Political Science Discipline, featured in this issue of PS. Later that evening, Ambassador Jeane J. Kirkpatrick addressed the opening session of the World Congress, speaking on the United Nations' peacekeeping role.

The triennial World Congress had never been held in the United States. To facilitate contacts between foreign and American political scientists the World Congress was scheduled to overlap one day, September I, with the APSA Annual Meeting. Almost 6,000 political scientists participated in the eight days of meetings.

\section{Program Participation}

Under the direction of Program Chair Harold Jacobson, 1,265 political scientists took part in 232 substantive sessions. Participation in the 1988 program was greater than either the 1985 Paris Congress $(1,059)$, or the 1979 Moscow Congress (846).

The 1988 participation levels reflect a substantial growth in the size of the Congress program. Jacobson and the members 